Egyptian Journal of Aquatic Biology \& Fisheries

Zoology Department, Faculty of Science,

Ain Shams University, Cairo, Egypt.

ISSN $1110-6131$

Vol. 25 (5): $409-418$ (2021)

www.ejabf.journals.ekb.eg

\title{
Identification of Bacterial Symbionts from the Marine Sponge Aaptos suberitoides
} (Demospongiae: Suberitidae)

\author{
Hafshoh Maisyaroh ${ }^{1}$, Rahayu Kusdarwati ${ }^{2}$, Heru Pramono ${ }^{3}$, Syafrina Sari Lubis ${ }^{4}$ \\ Farikhah ${ }^{5}$, Sapto Andriyono, ${ }^{3, *}$ \\ ${ }^{1}$ Aquaculture Study Program, Fisheries and Marine Faculty, Universitas Airlangga, Campus C of \\ Universitas Airlangga, Surabaya, East Java Indonesia \\ ${ }^{2}$ Department of Aquaculture, Fisheries And Marine Faculty, Universitas Airlangga, Campus C of \\ Universitas Airlangga, Surabaya, East Java Indonesia \\ ${ }^{3}$ Department of Marine, Fisheries And Marine Faculty, Universitas Airlangga, Campus C of \\ Universitas Airlangga, Surabaya, East Java Indonesia \\ ${ }^{4}$ Department of Biology, Ar-Raniry Islamic State University of Banda Aceh, Indonesia \\ ${ }^{5}$ Department of Aquaculture, Faculty of Agriculture, Muhammadiyah University of Gresik, East \\ Java, Indonesia \\ *Corresponding Author: sapto.andriyono@fpk.unair.ac.id
}

\begin{tabular}{|c|c|}
\hline ARTICLE INFO & ABSTRACT \\
\hline Article History: & The sponges are primitive multicellular animals (metazoans) that belong \\
\hline June 18,2021 & Porifera. They are symbiotic with bacteria, archaea, \\
\hline & algae and fungi, and the common symbionts organisms. Symbionts \\
\hline Onlin & $\begin{array}{l}\text { bacteria are obtained vertically through gametes and horizontal through the } \\
\text { filter feeder process. This study aimed to isolate and the species of }\end{array}$ \\
\hline $\begin{array}{l}\text { Keywords: } \\
\text { Sponges, } \\
\text { Symbiotic, } \\
\text { Bacteria, } \\
\text { Coastal water, } \\
\text { Diversity }\end{array}$ & $\begin{array}{l}\text { symbionts bacteria in Aaptos suberitoides sponge from Pasir Putih Beach } \\
\text { waters Situbondo, East Java. Six symbionts bacterial were isolated from the } \\
\text { sponge Aaptos suberitoides; namely, Corynebacterium hofmanni, Vibrio } \\
\text { damsela, Oligella urethralis, Bacillus coagulan and Bordetella } \\
\text { parapertusis. Biochemical tests confirmed that the symbiotic bacteria can } \\
\text { perform several processes: nitrification process, citrate, urease, Voges } \\
\text { Proskauer, decarboxylase lysine, and decarboxylase ornithine and } \\
\text { hydrolysis aesculin. In conclusion, excluding Bacillus coagulant bacteria, } \\
\text { symbionts bacterial were proved mostly pathogenic to humans and fish. }\end{array}$ \\
\hline
\end{tabular}

\section{INTRODUCTION}

Sponges are filter feeders known to be symbiotic with bacteria, archaea, microalgae and fungi. These microorganisms can contribute significantly to spongy metabolism (Taylor et al., 2007). Bacteria found to be symbiotic with sponges Aaptos sp. dominated by bacteria of the class Actinobacteria, Flavobacterium, Alphaproteobacteria, Deltaproteobacteria and Gammaproteobacteria (Chasanah et al., 2013). Sponges can produce chemical compounds as a form of self-defence response to predators and competitors (Taylor et al., 2007). The resulting chemical compounds can induce 
symbiotic microorganisms to produce specific secondary metabolites (Nofiani et al., 2009). The sponge Aaptos suberitoides produces aaptamine and demethylaaptamine compounds with cytotoxic activity (Hanif et al. 2019). Bacteria Rhodobacteraceae bacterium (Murniasih et al. 2014), Halomonas aquamarina, Alphaproteobacterium and Pseudoalteromonas luteviolaceae symbiotic with sponges og genus Aaptos sp. are known to produce antibacterial compounds (Radjasa et al., 2007). Identification of symbiotic bacterial species with sponges is essential for assessing the composition and function of the microbial community (Martin, 2002).

This study aimed to identify bacteria species that are symbiotic with marine sponges. The symbiotic bacteria are expected to be developed and become bioremediation candidates in cultivation activities such as shrimp pond processing and waste fish processing industry, which can decrease the water quality around the activity area.

\section{MATERIALS AND METHODS}

\section{Samples Collection}

Samples were taken from Pasir Putih beach water Situbondo at a depth of 12-14 meters. After the sponge was taken and cut, the samples were put in a cool box and seawater with fixed aeration. The samples were then taken to the laboratory to be identified and analyzed (Abubakar et al., 2011). Sponge identification refers to the world sponge database accessed through online database (www.marinespecies.org/porifera) and based on sponge morphology (Subagio \& Aunurohim, 2013).

\section{Isolation Bacterial Symbiont Sponge}

The sterilisation of the sponges surface was done with ethanol (70\%) and rinsed thrice with sterile seawater. The rinsed sponges were taken as much as one gram, smoothed using a mortar, and five (5) $\mathrm{mL}$ of sterile seawater was added on each sampled gram. The homogeneous solution was diluted by adding one (1) $\mathrm{mL}$ of the solution into nine (9) $\mathrm{mL}$ of sterile seawater, then the outcome was diluted to $10^{-3}$ of the initial concentration (Rua et al., 2014). The sample planting was done by surface/spread plate method [11] on Tryptic Soy Agar Sea Water (TSA-SW) media, and the TSA medium diluted with sterile seawater (Whitman et al., 2012). The cultured sample was an outcome of $10^{-1}$ to $10^{-3}$ dilution and was incubated at $30^{\circ} \mathrm{C}$ for one to three days (Cicirelli, 2007). The bacterial colonies were collected using a sterile ose. They were scraped on TSA-SW mediumand incubated for 48 hours at $30^{\circ} \mathrm{C}$ (Setyati \& Subagiyo, 2012)until a single colonywas obtained.

\section{Bacterial Isolate Identification}

Identification of spongy symbiont bacteria includes morphological and biochemical tests. Morphological tests include colony shape, colony colour, colony edge, elevation or 
colony surface, colony and Gram staining structures. Biochemical tests included catalase, oxidase, O/F, TSIA, nitrate reduction, gelatin, MR-VP, phenylalanine deaminase, urease, citrate utilisation, glucose, lactose, sucrose, maltose, mannitol, dulcitol, inositol, sorbitol, arabinose, raffinose and xylose, lysine, malonate, MIO and aesculine. The results of further identification tests were compared to Cowan and Steel's Manual for the Identification of Medical Bacteria (Cowan and Steel, 1965) and Bergey's Manual of Determinative Bacteriology (Whitman et al., 2012), which was used for the analysis and determination species from isolates of symbiotic bacteria.

\section{RESULTS}

\section{Isolation of Bacterial Symbiont}

Bacterial isolation from the Aaptos suberitoides spongy tissue was grown on Tryptic Soy Agar-Sea Water (TSA-SW) medium, selected by colour, size and colony shape. Based on the colony morphology, though seven (7) bacterial isolates were planted on TSA-SW media, only six (6) isolates were grown (Table 1). The six bacterial isolates were purified with the same medium for the identification process.

\section{Identification of Bacterial Symbiont}

The six isolate symbiont bacteria were then conventionally identified, including morphological and biochemical tests (Table 2). The identification results of each isolate of the symbiotic bacteria were compared with identification manuals, Cowan and Steel's Manual for the Identification of Medical Bacteria (Cowan \& Steel, 1965) and Bergey's Manual of Determinative Bacteriology (Whitman et al., 2012) to determine the species of bacteria.

Table 1. Colony morphology of bacterial symbionts on Aaptos suberitoides

\begin{tabular}{lclllccc}
\hline No. & isolate code & color & elevate & Edge & form & $\begin{array}{c}\text { size } \\
(\mathrm{mm})\end{array}$ & $\begin{array}{c}\text { isolate } \\
\text { growth }(+/-)\end{array}$ \\
\hline 1. & SC1 & white & Convex & Flat & rounded & 1.5 & + \\
2. & SC2 & cream & Convex & Flat & rounded & 1.0 & - \\
3. & SC3 & cream & Convex & Flat & amorf & 6.0 & + \\
4. & SC4 & cream & Convex & Flat & amorf & 2.0 & + \\
5. & SC5 & white & Convex & Flat & rounded & 1.0 & + \\
6. & SC6 & white & Convex & Flat & rounded & 2.0 & + \\
7. & SC7 & cream & Convex & Flat & rounded & 1.0 & + \\
\hline
\end{tabular}

\section{DISCUSSION}

Bacteria that are found and symbiotic with sponges have different characteristics.

The Corynebacterium hofmanni bacterium has another name; Corynebacterium pseudodiphtheriticum (Cowan \& Steel, 1965; Whitman et al., 2012). Corynebacterium hofmanni bacteria are normal bacteria in the human nasopharynx (Whitehouse et al., 2018). The bacteria of this genus are found to live in seawater (Mudryk, 1998), and one of the species of this genus; Corynebacterium maris,is found in Fungia granulosa coral 
mucus (Ben-Dov et al., 2009). Corynebacterium hofmanni bacteria rarely cause infections, but they can cause endocarditis, urinary tract infection (UTIs) and may infect skin lesions (Whitehouse et al., 2018).

Table 2. Morphological and biochemical tests of symbiotic sponge bacteria

\begin{tabular}{|c|c|c|c|c|c|c|}
\hline \multirow{2}{*}{ Parameter } & \multicolumn{6}{|c|}{ Isolate } \\
\hline & SC1 & SC3 & SC4 & SC5 & SC6 & SC7 \\
\hline \multicolumn{7}{|l|}{ Gram Characteristic } \\
\hline Bacterial form & coccus $^{*}$ & coccus & $\operatorname{coccus}^{* \wedge}$ & coccus & coccus ${ }^{*}$ & coccus ${ }^{*}$ \\
\hline Colour/Gram & $+*$ & $z^{*}$ & $-{ }^{*}$ & $-{ }^{*}$ & $+{ }^{*}$ & $-{ }^{*}$ \\
\hline \multicolumn{7}{|l|}{ Biochemistry Test } \\
\hline TSI Agar & $\mathrm{K} / \mathrm{K}$ & $\mathrm{A} / \mathrm{A}$ & $\mathrm{A} / \mathrm{A}$ & $\mathrm{K} / \mathrm{K}$ & $\mathrm{A} / \mathrm{A}$ & $\mathrm{K} / \mathrm{K}$ \\
\hline Gas & - & - & - & - & - & - \\
\hline $\mathrm{H}_{2} \mathrm{~S}$ & - & $-\hat{n}$ & $-\wedge$ & $-\wedge$ & - & - \\
\hline Catalase & $+*$ & $+^{*}$ & $+^{*}$ & $++^{* \wedge}$ & $++^{* \Lambda}$ & $+^{*}$ \\
\hline Oxidase & $-{ }^{*}$ & $++^{* \wedge}$ & $+{ }^{* \Lambda}$ & $+t^{* \Lambda}$ & - & $-^{* \Lambda}$ \\
\hline $\mathrm{O} / \mathrm{F}$ & $\mathrm{NR}^{*}$ & $\mathrm{~F}^{*}$ & $\mathrm{~F}$ & $\mathrm{NR}^{*}$ & NR & $\mathrm{NR}^{*}$ \\
\hline Nitrate Reduction & $+{ }^{* \lambda}$ & $-{ }^{* 1}$ & $-{ }^{* \Lambda}$ & $-^{* \wedge}$ & $+{ }^{*} \mathrm{~d}$ & $\mathrm{w}^{* \wedge}$ \\
\hline Gelatin & $-{ }^{*}$ & $-\wedge$ & $-\wedge$ & $-{ }^{*}$ & $-{ }_{-}^{\wedge d}$ & $-^{*}$ \\
\hline Motility & $-*$ & $+*$ & $+*$ & $-{ }^{*}$ & $+{ }^{* 1}$ & $-{ }^{*}$ \\
\hline Indole & - & $-{ }^{* \lambda}$ & $-{ }^{* \wedge}$ & $-\hat{n}$ & $-*$ & - \\
\hline Simmons Citrate & + & $+t^{\wedge}$ & $+\wedge$ &.$-^{* d}$ & $-{ }^{d}$ & $-{ }^{* 1}$ \\
\hline Malonate & - & $-\wedge$ & $-\wedge$ & - & - & - \\
\hline Christine's Urease & $+{ }^{* \wedge}$ & $--^{* \wedge}$ & $-{ }^{* \Lambda}$ & $-{ }^{* \wedge}$ & $+{ }^{* \wedge}$ & $--^{* \wedge}$ \\
\hline Methyl Red (MR) & $-{ }^{\wedge}$ & - & - & - & - & - \\
\hline Voges Proskauer (VP) & $-{ }^{*}$ & $++^{*+1}$ & $+{ }^{* \Lambda}$ & - & $-{ }_{-}^{\mathrm{dd}}$ & - \\
\hline Lysine Decarboxylase & - & $-{ }^{* \Lambda}$ & $-^{* \Lambda}$ & + & $-\wedge$ & $+\wedge$ \\
\hline Ornithine Decarboxylase & + & - & $-{ }^{* 1}$ & + & $++^{\wedge}$ & + \\
\hline Phenylalanine Deaminase & - & $-\wedge$ & $-\wedge$ & - & - & - \\
\hline Aesculin Hydrolysis & $-^{* \wedge}$ & $+\wedge$ & $+\wedge$ & - & $-{ }_{-}^{\wedge} \mathrm{d}$ & - \\
\hline \multicolumn{7}{|c|}{ Carbohydrate Fermentation } \\
\hline Glucose & - - & $+{ }^{* 1}$ & $+{ }^{* \wedge}$ & $-{ }^{*}$ & $+{ }^{* \wedge}$ & $-{ }^{*}$ \\
\hline Lactose & $-{ }^{*}$ & $-^{\wedge}$ & $-^{\wedge}$ & - & $++^{\wedge d}$ & - \\
\hline Sucrose & $-*$ & $+*$ & $+*$ & - & $+^{\wedge d}$ & - \\
\hline Maltose & - & $+\wedge$ & $+{ }^{\wedge}$ & $-{ }^{*}$ & $+\wedge$ & $--^{*}$ \\
\hline Mannitol & $-{ }^{*}$ & $+\wedge$ & $+\wedge$ & - & $-\wedge$ & - \\
\hline Dulcitol & - & $-\wedge$ & $-\wedge$ & - & $-\wedge$ & - \\
\hline Inositol & - & $-\wedge$ & $-\wedge$ & - & - & - \\
\hline Sorbitol & - & $-\wedge$ & $-\wedge$ & - & $-{ }^{\wedge} \mathrm{d}$ & - \\
\hline Arabinose & - & $-{ }^{* 1}$ & $-{ }^{* \prime \prime}$ & - & $-^{\wedge d}$ & - \\
\hline Raffinose & - & $-\wedge$ & $-\wedge$ & - & $-{ }^{*}+\wedge d$ & - \\
\hline Xylose & - & $-{ }^{*}$ & $-{ }^{* \prime \prime}$ & - & $-^{* 1}$ & - \\
\hline Genus & $\begin{array}{c}\text { Corynebacteri } \\
\text { um }\end{array}$ & Vibrio & Vibrio & Oligella & Bacillus & Bordetella \\
\hline Species & C. hofmannii & V.damsela & V.damsela & $\begin{array}{c}\text { O.uretral } \\
\text { is }\end{array}$ & $\begin{array}{c}\text { B. } \\
\text { coagulans }\end{array}$ & $\begin{array}{c}B . \\
\text { Parapertu } \\
\text { ssis }\end{array}$ \\
\hline
\end{tabular}

Remark: (+) = Positive; (-) = Negative; A = Acid; K = Alkaline; NR = Non Reaction; F = Fermentative; W = weak;

$\mathrm{d}=\mathbf{1 6 - 8 4 \%}$ strain positive

The bacterium Vibrio damsela or now known as Photobacterium damselae subsp. damselae (Rivas et al., 2011) can be found in some damselfish sea fish, yellowtail, seabream, and brown shark. Another report explained that these bacteria are also common in lemon sharks, dolphins, turtles, octopus, uninfected fish and wounds in 
humans. These bacteria can cause ulcers in Chromis punctipinnis fish and cause infection in human wounds (Brenner et al., 2005). Bacteria Photobacterium damselae has been isolated from the marine sponges, family Geodiidae and Halichondriidae (Sfanos $\boldsymbol{e t}$ al., 2005). Other photobacterium bacterial species known to be symbiotic with marine sponges are known as Photobacterium rosenbergii (Thompson et al., 2005), Photobacterium jeanii (Chimetto et al., 2010) and Photobacterium phosphoreum (Sfanos et al., 2005). In addition, Vibrio sp. bacteria are present in the water of white shrimp (Litopenaeus vannamei). If the abundance of bacteria Vibrio sp. in white shrimp exceed the minimum threshold of bacteria in the waters of $10^{4} \mathrm{CFU} / \mathrm{ml}$, it becomes susceptible to the attack of Vibriosis (Kharisma \& Manan, 2012).

Oligella uretralis, formerly known as Moraxella urethralis (Brenner et al., 2005), is a bacterium that is generally susceptible to most antibiotics. It was observed that this bacterium is susceptible to penicillin (Welch et al., 1983). Oligella urethralis is widespread (Rossau et al., 1987) but it is primarily isolated from the human urogenital tract and has been reported to cause urosepsis (Pugliese et al., 1993). Some Oligella urethralis are also isolated from ear, blood and leg wounds (Rossau et al., 1987; Brenner et al., 2005) . These bacteria have also been isolated from rabbit conjunctiva (Marini et al., 1996). This genus, Oligella ureolytica, has been isolated from GokceadaTurkey island in the coastal and offshore areas (Türetken \& Altuğ, 2016).

The Bacillus coagulant has been found in corneal infections, bacteremia and cow abortions. These bacteria are also found in compost, milk, paper, cardboard and silage (De Vos \& Garrity, 2009). They are also found in gemstones (Khan et al., 2001). In addition, they were isolated from Gokceada-Turkey Island in the coastal and offshore areas (Türetken \& Altuğ, 2016). Bacillus coagulan bacteria have an essential role in food spoilage as a producer of commercially valuable products such as lactic acid, thermostable enzymes, and antimicrobial peptides coagulin, and are used as probiotics (De Vos \& Garrity, 2009). This bacterium was known to play a role in degrading chitin (Clements et al., 2002). Several Bacillus species have been isolated from marine sponges; namely, Bacillus benzoevorans, Bacillus cereus, Bacillus firmus, Bacillus gibsonii, Bacillus methanolicus, Bacillus niacini, Bacillus pumilus, Bacillus sp., Bacillus anthracis and Bacillus vietnamensis (Sfanos et al., 2005). Furthermore, Bordetella parapertusis bacteria have been found in the human respiratory tract (Wolfe et al., 2005) and sheep (Martin, 1996). One species of this genus Bordetella petrii isolated from the sea sponges of the family Coelosphaeridae and Pseudoceratinidae (Sfanos et al., 2005). Bordetella parapertusis bacteria can cause mild pertussis in humans and cause chronic progressive pneumonia in sheep (Brenner et al., 2005).

The acquired bacterial symbionts can perform several processes in the body of the sponge. Collectively the microbes in the sponge can perform many processes, such as photosynthesis, methane oxidation, nitrification, nitrogen fixation, sulfate reduction, and dehalogenation (Taylor et al., 2007). Bacterial symbionts are also involved in various 
processes of sponge metabolism, such as vitamin production, nutrient transport, utilisation, redox sensing and response (Thomas et al., 2010).

The data obtained showed that the mechanisms of these bacteria in the sponges body are vertical. Vertical transmission is transmitted through sponge gametes through oocytes or sponge larvae (Aknin et al., 2010). The vertical transmission process of the sponge begins with the inclusion of the symbiotic bacteria present in mesohyl into the oocyte by phagocytosis. During the process of the division of the embryo, bacteria exist between blastomeres or are found in vacuoles. In the blastula, all bacteria are removed in the blastocoele (Ereskovsky et al., 2005). The presence of bacterial cells in the central cavity of the embryo (blastocele) is consistent with the description of bacteria present in the larval cavity (Sharp et al., 2007).

Based on the sponge properties of the filter feeder, there is a possibility of horizontal transmission. Horizontal transmission is the bacterial selective absorption process of bacterial diversity in the surrounding water column that passes through the sponge during the filter feeder process (Taylor et al., 2007). Known bacteria found in coastal waters of Pasir Putih Situbondo are Pseudomonas cepacia, Bacilus subtilis and Vibrio alginolyticus (Andriyono et al., 2015). Pseudomonas cepacia or Burkholderia cepacia was found in Aplysina fulva marine sponges in coastal waters of Brazil (Hardoim et al., 2009). Bacilus subtilis bacteria have also been isolated from marine sponges Haliclona simulans (Phelan et al., 2013) and Fasciospongia cavernosa (Pandey et al., 2014). The Vibrio algilinolitycus is known as symbiotic bacteria with a sea sponge Algelas sp. and Spongia sp. (Hassanzadeh et al., 2014). However, the current study did not find the three species of bacteria on the body of the Aaptos suberitoides sponge as a symbiont. This condition is possible due to the selection process in the body of the sponge during the filter feeder process. Sponges have an effective defence system against microbes and parasites involving bacterial engulfment into specialised cells, beside the fact that sponges also use signal pathways that actively kill bacteria transduction. The archaeocyte cell in the sponge body can be thought of as the macrophage of the sponge, where it is used for self-defense against foreign microorganisms (Müller \& Müller, 2003).

\section{CONCLUSION}

This study has obtained isolates that are symbiotic with Aaptos suberitoides. Symbiotic bacteria with Aaptos suberitoides spongewere isolated and identified as Corynebacterium hofmanni, Vibrio damsela, Oligella urethralis, Bacillus coagulant and Bordetella parapertusis. The bacteria can not be used as bioremediation agents because most bacteria are pathogenic to humans and fish, except Bacillus coagulant. However, further research is required to determine the effect of bacteria as a probiotic agent candidate on bioremediation. 


\section{REFERENCES}

Abubakar, H.; Wahyudi, A. T. and Yuhana, M. (2011). Skrining bakteri yang berasosiasi dengan spons Jaspis sp. sebagai penghasil senyawa antimikroba. ILMU KELAUTAN: Indonesian Journal of Marine Sciences, 16(1) : 35-40.

Aknin, M.; Gros, E.; Vacelet, J.; Kashman, Y. and Gauvin-Bialecki, A. (2010). Sterols from the Madagascar Sponge Fascaplysinopsis sp. Marine drugs, 8(12) :2961-2975.

Andriyono, S.; Jalasena, B.; Tjahtjaningsih, W. and Pramono, H. (2015). Characterisation of Symbiotic Bacteria Isolated from Sponge Haliclona sp. Exploration and Conservation of Biodiversity, The First International Conference On Life Sciences And Biotechnology 2015 :110-115.

Ben-Dov, E.; Yosef, D. Z. B.; Pavlov, V. and Kushmaro, A. (2009). Corynebacterium maris sp. nov., a marine bacterium isolated from the mucus of the coral Fungia granulosa. International journal of systematic and evolutionary microbiology, 59(10): 2458-2463.

Brenner, D. J.; Krieg, N.; Staley, J. and Garrity, G. (2005). Bergey's manual of systematic bacteriology, Vol 2: The Proteobacteria. NY: Springer.

Chasanah, E.; Patantis, G.; Dewi, A. S.; Marraskuranto, E.; Januar, H. I.; Stella, S.; Soka, S. and Yogiara, Y (2013). Analysis of Bacterial Community Associated with Aaptos sp. from Rote and Seribu Islands. Microbiology Indonesia, 7(1) :5-5.

Chimetto, L. A.; Cleenwerck, I.; Thompson, C. C.; Brocchi, M.; Willems, A.; De Vos, P. and Thompson, F. L. (2010). Photobacterium jeanii sp. nov., isolated from corals and zoanthids. International journal of systematic and evolutionary microbiology, 60(12) :2843-2848.

Cicirelli, E. M. (2007). Bacterial quorum-sensing in the marine sponge environment: Implications on motility and flagellar biosynthesis. Indiana University.

Clements, L. D.; Miller, B. S. and Streips, U. N. (2002). Comparative growth analysis of the facultative anaerobes Bacillus subtilis, Bacillus licheniformis, and Escherichia coli. Systematic and applied microbiology, 25(2) :284-286.

Cowan, S. T., and Steel, K. J. (1965). Manual for the identification of medical bacteria. Manual for the Identification of Medical Bacteria.

De Vos, P. and Garrity, G. M. (2009). Bergey's manual of systematic bacteriology: Springer.

Ereskovsky, A. V.; Gonobobleva, E. and Vishnyakov, A. (2005). Morphological evidence for vertical transmission of symbiotic bacteria in the viviparous sponge Halisarca dujardini Johnston (Porifera, Demospongiae, Halisarcida). Marine Biology, 146(5) :869-875.

Hanif, N.; Murni, A.; Tanaka, C. and Tanaka, J. (2019). Marine natural products from Indonesian waters. Marine drugs, 17(364):1-69. 
Hardoim, C.; Costa, R.; Araujo, F.; Hajdu, E.; Peixoto, R.; Lins, U.; Rosado A, S. and Van Elsas, D.J. (2009). Diversity of bacteria in the marine sponge Aplysina fulva in Brazilian coastal waters. Applied and environmental microbiology, 75(10): 3331-3343.

Hassanzadeh, Y.; Bahador, N. and Baseri Salehi, M. (2014). Isolation and Identification of symbiotic Vibrio alginolyticus from Persian Gulf sponges with API 20NE kit. Journal of Marine Biology, 6(3) :61-68.

Khan, M.; Saha, M. and Afroz, H. (2001). Microorganisms associated with gemstones. Bangladesh Journal of Botany, 30(2) :93-96.

Kharisma, A. and Manan, A. (2012). Kelimpahan Bakteri Vibrio sp. pada air pembesaran udang vannamei (Litopenaeus vannamei) sebagai deteksi dini serangan penyakit vibriosis. Jurnal Ilmiah Perikanan dan Kelautan, 4(2) :128134.

Marini, R. P.; Foltz, C. J.; Kersten, D.; Batchelder, M.; Kaser, W. and Li, X. (1996). Microbiologic, radiographic, and anatomic study of the nasolacrimal duct apparatus in the rabbit (Oryctolagus cuniculus). Laboratory animal science, 46(6) :656-662.

Martin, A.P. (2002). Phylogenetic approaches for describing and comparing the diversity of microbial communities. Applied and Environmental Microbiology 68 (8) :3673-3682.

Martin, W. (1996). Respiratory infections of sheep. Comparative immunology, microbiology and infectious diseases, 19(3):171-179.

Mudryk, Z. (1998). Generic composition and metabolic activity of bacteria inhabiting surface seawater layers. Oceanological Studies, 27(3) :57-70.

Müller, W. E. and Müller, I. M. (2003). Origin of the metazoan immune system: identification of the molecules and their functions in sponges. Integrative and comparative biology, 43(2) :281-292.

Murniasih, T.; Kosela, S.; Kardono, L. B.; Hanafi, M. and Suwarso, W. P. (2014). An antibacterial compound isolated from sponge-associated bacteria Rhodobactercicea bacterium. Journal of Medical Sciences (Faisalabad), 14(2) :75-80.

Nofiani, R.; Nurbetty, S., and Sapar, A. (2009). Aktivitas Antimikroba Ekstrak Metanol Bakteri Berasosiasi Spons Dari Pulau Lemukutan, Kalimantan Barat Antimicrobial Activities Of Methanol Extract From Unidentified Sponge Associated Bacteria In Lemukutan Island, Kalimantan Barat. E-Jurnal Ilmu dan Teknologi Kelautan Tropis, 1(2),:33-41.

Pandey, S.; Sree, A.; Sethi, D. P.; Kumar, C. G.; Kakollu, S.; Chowdhury, L. and Dash, S. S. (2014). A marine sponge associated strain of Bacillus subtilis and other marine bacteria can produce anticholinesterase compounds. Microbial cell factories, 13(1) :1-9. 
Phelan, R. W.; Barret, M.; Cotter, P. D.; O'Connor, P. M.; Chen, R.; Morrissey, J. P.; Dobson, A.D.W.; O'Gara, F. and Barbosa, T. M. (2013). Subtilomycin: a new lantibiotic from Bacillus subtilis strain MMA7 isolated from the marine sponge Haliclona simulans. Marine drugs, 11(6) :1878-1898.

Pugliese, A.; Pacris, B.; Schoch, P. E. and Cunha, B. A. (1993). Oligella urethralis urosepsis. Clinical infectious diseases, 17(6) :1069-1070.

Radjasa, O. K.; Kencana, D. S.; Sabdono, A.; Hutagalung, R. A. and Lestari, E. S. (2007). Antibacterial activity of marine bacteria associated with sponge Aaptos sp. against Multi Drugs Resistant (MDR) strains. Jurnal Matematika dan sains, 12(4):147-152.

Rivas, A. J.; Balado, M.; Lemos, M. L. and Osorio, C. R. (2011). The Photobacterium damselae subsp. damselae hemolysins damselysin and HlyA are encoded within a new virulence plasmid. Infection and Immunity, 79(11) :4617-4627.

Rossau, R.; Kersters, K.; Falsen, E.; Jantzen, E.; Segers, P.; Union, A.; Nehls, L. and De Ley, J. (1987). Oligella, a new genus including Oligella urethralis comb. nov.(formerly Moraxella urethralis) and Oligella ureolytica sp. nov.(formerly CDC group IVe): relationship to Taylorella equigenitalis and related taxa. International journal of systematic and evolutionary microbiology, 37(3) :198210.

Rua, C. P.; Trindade-Silva, A. E.; Appolinario, L. R.; Venas, T. M.; Garcia, G. D.; Carvalho, L. S.; lima, A.; Kruger, R.; Pereira, R.C.; Berlinck, R.G.S.; Valle, R, A.B.; Thompson, C.C. and Thompson, F (2014). Diversity and antimicrobial potential of culturable heterotrophic bacteria associated with the endemic marine sponge Arenosclera brasiliensis. PeerJ, 2, e419.

Setyati, W. A. and Subagiyo, S. (2012). Isolasi dan Seleksi Bakteri Penghasil Enzim Ekstraseluler (proteolitik, amilolitik, lipolitik dan selulolitik) yang Berasal dari Sedimen Kawasan Mangrove (Isolation and Selection of Extracellular Enzyme Producing Bacteria Originating from Mangrove Sedimen. ILMU KELAUTAN: Indonesian Journal of Marine Sciences, 17(3) :164-169.

Sfanos, K.; Harmody, D.; Dang, P.; Ledger, A.; Pomponi, S.; McCarthy, P. and Lopez, J. (2005). A molecular systematic survey of cultured microbial associates of deep-water marine invertebrates. Systematic and applied microbiology, 28(3),:242-264.

Sharp, K. H.; Eam, B.; Faulkner, D. J. and Haygood, M. G. (2007). Vertical transmission of diverse microbes in the tropical sponge Corticium sp. Applied and environmental microbiology, 73(2),:622-629.

Subagio, I. B. and Aunurohim, A. (2013). Struktur Komunitas Spons Laut (Porifera) di Pantai Pasir Putih, Situbondo. Jurnal Sains dan Seni ITS, 2(2) :159-165. 
Taylor, M. W.; Radax, R.; Steger, D. and Wagner, M. (2007). Sponge-associated microorganisms: evolution, ecology, and biotechnological potential. Microbiology and molecular biology reviews, 71(2):295-347.

Thomas, T., Rusch, D., DeMaere, M. Z., Yung, P. Y., Lewis, M., Halpern, A., Heidelberg, K.B., Egan, S., Steinberg, P. D., Kjelleberg, S. (2010). Functional genomic signatures of sponge bacteria reveal unique and shared features of symbiosis. The ISME journal, 4(12) :1557-1567.

Thompson, F.L; Thompson, C.C; Naser, S.; Hoste, B.; Vandemeulebroecke, K.; Munn, C.; Bourne, D. and Swings, J. (2005). Photobacterium rosenbergii sp. nov. and Enterovibrio coralii sp. nov., vibrios associated with coral bleaching. International journal of systematic and evolutionary microbiology, 55(2), :913917.

Türetken, P. S. Ç. and Altuğ, G. (2016). Bacterial pollution, activity and heterotrophic diversity of the northern part of the Aegean Sea, Turkey. Environmental monitoring and assessment, 188(122) :1-12.

Welch, W.; Porschen, R. and Luttrell, B. (1983). Minimal inhibitory concentrations of 19 antimicrobial agents for 96 clinical isolates of group IVe bacteria. Antimicrobial agents and chemotherapy, 24(3):432-433.

Whitehouse, C. A.; Zhao, S., and Tate, H. (2018). Antimicrobial resistance in Campylobacter species: mechanisms and genomic epidemiology. Advances in applied microbiology, $103: 1-47$

Whitman, W. B.; Goodfellow, M.; Kämpfer, P.; Busse, H.-J.; Trujillo, M. E.; Ludwig, W. and Suzuki, K.-i. (2012). Bergey's manual of systematic bacteriology: Volume 5: The Actinobacteria: Springer New York.

Wolfe, D. N.; Kirimanjeswara, G. S. and Harvill, E. T. (2005). Clearance of Bordetella parapertussis from the lower respiratory tract requires humoral and cellular immunity. Infection and Immunity, 73(10) :6508-6513. 